\title{
ATOPINIS DERMATITAS: ŠIUOLAIKINIS POŽIŪRIS
}

\author{
Doc. dr. Palmira Leišyte \\ KMU Vidaus ligu klinika
}

\begin{abstract}
REIKŠMINIAI ŽODŽıAI: atopinis dermatitas, egzema, alergija, diagnostika, odos testai, gydymas.
SANTRAUKA. Atopinis dermatitas (AD) yra lètinè odos uždegimo liga, kuriai būdingas pasikartojantis stiprus niežẻjimas, nuo amžiaus priklausoma išbeirimų lokalizacija ir tam tikras išberimų pobūdis. Daugiau kaip 85 proc. vaikų suserga šia liga iki 5 metu, o pirmaisiais gyvenimo metais - net 60 proc. Suaugus liga prasideda 16,8 proc. pacientu. Iki šiol tebediskutuojama dèl alergijos j̨takos atopiniam išberimui. Suaugusiuosius labiau veikia ¡̨kvepiamieji alergenai, vaikus - maisto alergenai. Alergijai nustatyti dažniausiai atliekami odos dūrio mėginiai, tiriami specifiniai lgE kraujo serume. Pastaraisiais metais išskiriama grupe pacientų, kuriems nustatoma IV tipo sensibilizacija atliekant atopinius lopo méginius.
\end{abstract}

Atopinis dermatitas (AD) - lètinè odos uždegimo liga, kuriai būdingas pasikartojantis stiprus niežèjimas, nuo amžiaus priklausoma išbėrimų lokalizacija ir tam tikras pobūdis [1]. Daugiau kaip 85 proc. vaikų suserga šia liga iki 5 metu amžiaus, o pirmaisiais gyvenimo metais net 60 proc. [2]. Suaugus liga prasideda tik 16,8 proc. pacientuc [3].

\section{DIAGNOSTIKA}

AD diagnozuojamas pagal klasikinius J. M. Hanifin ir G. Rajka (1980 m.) kriterijus [4]. AD diagnozuoti būtini trys didieji ir trys mažieji klasikiniai kriterijai.

\section{Didieji diagnostikos kriterijai}

- Tipiškos odos pažeidimo vietos:

- kūdikiams - veidas ir galūnių tiesiamieji paviršiai;

- vyresniems - veidas ir galūnių lenkiamieji paviršiai;

- Niežejjimas;

- Lètinè ligos eiga;

- Gretutinès alerginès ligos anamnezèje;

- Geneologinè anamnezè - alerginès ligos šeimoje.

\section{Mažieji diagnostikos kriterijai}

- Odos sausumas:

- Ankstyva ligos pradžia;

- Niežejimas prakaituojant;

- Baltasis dermografizmas;

- Veido blyškumas/raudonis;

- Periorbitinės raukšlès (Dennie Morgan);

- Cheilitas;

- Paryškejjusios padų ir delnų raukšlès;

- Imlumas odos infekcijoms;

- Baltoji pitiriazé;

- Vilnos ir tirpikliuc netoleravimas;

- Maisto netoleravimas;

- Odos imlumas infekcijoms (ypač auksiniam stafilokokui ir herpeso virusui)
- Üminès I tipo odos reakcijos;

- Padidèjęs IgE kiekis serume;

- Kartotinis konjunktyvitas;

- Polinkis ị nespecifinị rankų ir pèdų dermatitą;

- Folikulinè keratozè

- Aplinkos ir emocinių veiksnių itaka ligai;

- Oftalmologiniai: keratokonusas, priekiné subkapsulinè katarakta ir kt.

Diagnozuojant sunkumų kyla, kai reikia atskirti ịvairias egzemos formas, ypač suaugusiesiems, esant mišrių atopinès, kontaktinès ir iritacinès - egzemos požymių. Rankų ir pėdų atopinę egzemą reikia skirti nuo delnų ir pẻdų žvynelinès, odos grybelinès infekcijos. Tenka AD atskirti ir nuo niežų, kartais - odos T ląstelių limfomos (grybiškos granuliomos, mycosis fungoides).

Iki šiol tebediskutuojama dèl alergijos ittakos atopiniam išbèrimui, jo kartojimuisi. Suaugusiuosius labiausiai veikia ikvepiamieji alergenai, vaikus - maisto [1] Atopinis dermatitas vaikysteje laikomas net alergijos maistui simptomu.

\section{Alerginiai tyrimai}

Diagnozuojant alergiją maistui atliekami alerginiai odos dūrio méginiai, tiriami specifiniai IgE kraujo serume, bet auksinis alergijos maistui diagnozavimo standartas yra dvigubai akli maisto provokaciniai méginiai [14] Pastaraisiais metais išskiriama grupe pacientų, kuriems nustatoma IV tipo sensibilizacija atliekant atopinius lopo mėginius, bet klinikinę šios sensibilizacijos reikšmę būtina patvirtinti ir provokaciniu mėginiu [5].

Daugelis atopiniu dermatitu sergančių ligonių esti ịsijautrinę įkvepiamiesiems alergenams. Jiems kuriuo nors būdu patekus ị organizmą, alerginis dermatitas paūmejja. Sensibilizacija nustatoma alerginiais odos dūrio méginiais, radus specifinių IgE kraujo serume, taip pat atopiniais lopo mėginiais (IV tipo sensibilizacija). Svarbiausi yra namų dulkių erkių, gyvūnų epidermio ir žie- 
dadulkių alergenai. Suaugusiesiems itin aktuali alergija namų dulkių erkių alergenams, kuri patvirtinama atopiniais lopo méginiais, dideliais specifinių IgE serume titrais, alergeno eliminacijos tyrimais. Stengiantis apsisaugoti nuo įkvepiamųjų alergenų, ypač kai yra alergija namų dulkių erkèms, odos pažeidimai gali gerokai palengvèti [6, 13].

Atopinis lopo mėginys. Pastarąji dešimtmeti paskelbta daug publikacijų apie atopinių lopo méginių reikšmę pagrindžiant IV tipo sensibilizaciją $[9,10,11,12]$. Atopinis odos lopo méginys atliekamas su maisto ar ikvepiamaisiais alergenais, galinčiais sukelti su IgE susijusias reakcijas; rezultatas vertinamas po $48-72$ val. Šių méginių biopsinès medžiagos tyrimai rodo esant alergenui specifinių $\mathrm{T}$ limfocitų klonų. Iš pradžių $\mathrm{T}$ limfocitams būdinga TH2 pobūdžio sekrecija, o po 48 val. vyrauja TH1 pobūdžio sekrecija, kaip ir esant lètiniams AD pažeidimams. IgE, prisijungęs prie odos Langerhanso ląstelių Fc receptorių, palengvina alergeno pernašą odos $T$ limfocitams.

Indikacijos atlikti atopinị lopo mėginị:

- Ittariamas issijautrinimas maisto arba ikvepiamiesiems alergenams, kai nèra specifinių IgE antikūnų, o odos dūrio mėginys (ODM) neigiamas.

- Sunkus ir/arba nuolatinis AD, kai neaiškūs provokuojamieji veiksniai.

- Su IgE susijusi dauginè sensibilizacija, kai neịrodyta klinikinè šių alergenų svarba AD eigai.

Daugeliu AD atvejų būna padidejusi IgE koncentracija. Tikètina, kad ji siejasi su ligos sunkumu, mat nustatyta, jog ant epidermio Langerhanso ląstelių paviršiaus yra IgE ir su IgE susijusių struktūrų [7].

Dažnas AD sergantis suaugusysis įsijautrina ir kontaktiniams alergenams - tepalams, vartojamiems dermatitui gydyti. Šio pobūdžio sensibilizaciją taip pat privalu atpažinti ir patvirtinti lopo méginiais.

Atopijos rizikos požymiai. Net nesant akivaizdžių $\mathrm{AD}$ požymių, iš prigimties i alergiją linkusių žmonių odoje yra minimalių, beveik nepastebimų, subtilesnių, tikriausiai genetiškai nulemtų odos pokyčių, kurie itin dažni sergant alerginiu rinitu ir alergine astma: Dennie Morgan raukšlè, Hertoghé požymis, sausa oda, padidèjęs odos jautrumas nespecifiniams dirgikliams. Šių

\section{ATOPIC DERMATITIS, ECZEMA, ALLERGY, DIAGNOSIS, SKIN TESTS, TREATMENT \\ Palmira Leišyte \\ Clinic of Internal Diseases \\ Kaunas University of Medicine}

Key words: atopic dermatitis, eczema, allergy, diagnosis, skin tests, treatment. Summary. Atopic dermatitis is a chronic pruritic inflammatory skin disease with typical pattern of eruption, which varies with age (1). AD occurs during the first year of life in $60 \%$ and before the age of 5 years in at least $85 \%$ of affected children (2). In adults with atopic dermatitis, only $16,8 \%$ had onset after adolescence. Sensitization to different allergens is often seen in patients with AD, but the role of allergy is a target for discussion. Food allergens are more important in children, inhalant allergens - in adults. Skin prick tests, measurement of serum specific $\lg E$ are used to diagnose a true lgE-mediated sensitization. The atopy patch test is of interest for the diagnosis of some patients. metu publikacijose teigiama, kad smulkios rausvos dèmès ar tinklinè eritema bei baltos dèmès delnų odoje gali būti pirmas požymis, rodantis atopijos riziką, ypač tais atvejais, kai yra būdinga anamnezè ir daug raukšliuc delnuose. Specifinių IgE nustatymas galètų paremti diagnozę. Paplitęs baltasis dermografizmas, paradoksinè kraujagyslių reakcija ị šiluminius dirgiklius dèl polinkio susitraukti esant atopijai - taip pat reikšmingi požymiai, atkreipiantys dèmesi i i atopinę prigimtị [8].

\section{GYDYMAS $[9,15]$}

Gydymo pagrindas - optimali odos priežiūra: reguliarus minkštinamųjų medžiagụ vartojimas ir odos drèkinimas, vengimas specifinių (maisto ir ịkvepiamųjų alergenų, jei tokia alergija patvirtinta) ir nespecifinių dirgiklių (vilnonių, sintetinių rūbų, netinkamo muilo, karšto vandens).

Minkštinamosios medžiagos pasirenkamos atsižvelgiant ị odos tipą, sezoną, klimato sąlygas, paros laiką. Skiriamos vandens aliejinè arba aliejaus vandeninè emulsijos. Minkštinamosios priemonès su polidokanoliu mažina niežèjimą, su šlapalu - intensyviai drèkina odą, su salicilo rūgštimi - gydo suragejjimus.

Ūminiam išbèrimui gydyti skiriama gliukokortikoidụ kremų ir tepalų, lengvas ir vidutinio sunkumo atopinis dermatitas gali būti gydomas vietinio poveikio kalcineurino inhibitoriais, pasižyminčiais imunomoduliuojamuoju poveikiu, jų skiriama tepti jautrioms odos vietoms (veido, kaklo, tarp odos raukšlių).

Vietinio poveikio antiseptikai (triklozanas, chlorheksidinas) mažina auksinio stafilokoko kolonizaciją odoje, kartu ir AD simptomus (stafilokoko išskiriami toksinai veikia kaip superantigenai). Veiksmingai stafilokoką veikia ir fucidino rūgšties kremas (2 savaičių kursas). Suaugusiųjų atopiniam dermatitui gydyti taikoma fototerapija. Neseniai atliktu daugiacentriu atsitiktinių imčių tyrimu nustatytas nuo dozès priklausomas specifinès imunoterapijos veiksmingumas gydant atopini dermatitą, kai yra ìsijautrinimas namų dulkių erkèms [16]. Antihistamininiai vaistai padeda nuslopinti niežuli. Sunkiais atvejais, ligai paūmejjus gydoma kursu geriamųjų gliukokortikoidų, ciklosporinu A, azatioprinu, infekcijai išplitus - sisteminiais antibiotikais, preparatais nuo grybelio.

\section{LITERATŪRA}

1. Zuberbier T, Worm M. Allergies and the skin, an interdisciplinary approach in GA2LEN and EAACl activities // Allergy 2006:61:1373-1376

2. Kay J, Gawkrodger DJ, Mortimer M.J, Jaron AG. The prevalence of childhood atopic eczema in a general population // J Am Acad Dermatol 1994; 30:35-9.

3. Ozkaya E. Adult-onset atopic dermatitis // J Am Acad Dermatol 2005; 52:579-82.

4. Ėmužytė R, Dubakienè R, Kuzminskienè $R$ ir kt. Atopinio dermatito diagnostika ir gydymas. Mokomoji metodinè medžiaga (sutarimas) // Alerginès odos ligos: dabartis ir perspektyvos. Vilnius, 2004. 41-55.

5. Turjanmaa K, Darsow U, Niggemann B et al. EAACI/GA2LEN Position paper: present status of the atopy patch test // Allergy 2006;61:13771384.

6. Tan B, Weald D, Strickland I et al. Double-blind controlled trial of effect of house-dust mite allergen avoidance on atopic dermatitis // Lancet 1996; 347: 15-18.

7. Laske N, Niggemann B. Does the severity of AD correlate with serum IgE levels? // Pediatr Allergy Immunol 2004; 15:86-88. 